\title{
Neuroptera of Canada
}

\author{
David C.A. Blades' \\ I Research Associate, Royal British Columbia Museum, 675 Belleville St, Victoria, BC, V8W 9W2, Canada \\ Corresponding author: David C.A. Blades (dcblades@gmail.com)
}

Academic editor: C. Sheffield | Received 15 May 2018 | Accepted 31 July 2018 | Published 24 January 2019

http://zoobank.org/4B9BAD83-87D8-49D4-B9C4-7B55EEA9F6B9

Citation: Blades DCA (2019) Neuroptera of Canada. In: Langor DW, Sheffield CS (Eds) The Biota of Canada A Biodiversity Assessment. Part 1: The Terrestrial Arthropods. ZooKeys 819: 387-392. https://doi.org/10.3897/ zookeys.819.26683

\begin{abstract}
The Neuroptera of Canada consists of 101 extant species, an increase of 26 (35\%) since the previous assessment of the fauna in 1979. More than 48 additional species are believed to occur in Canada based largely on recent DNA evidence and new distribution records. The Barcode Of Life Data System (BOLD) currently includes 141 Barcode Index Numbers (BINs) for Canadian Neuroptera. Canadian fossils have thus far yielded 15 species in three families of Neuroptera.
\end{abstract}

\section{Keywords}

antlion, aphidlion, biodiversity assessment, Biota of Canada, lacewing, mantidfly, Neuroptera, owlfly

The order Neuroptera, including the lacewings, antlions, owlflies and relatives, contains approximately 6400 extant species worldwide (Oswald and Machado 2018), and approximately 350 in America north of Mexico (Penny et al. 1997). As of 2017, the Canadian fauna consists of 101 extant species, an increase of nearly $35 \%$ since the previous assessment by Kevan (1979) (Canadian Endangered Species Conservation Council 2016) (Table 1).

The significant increase in species known from Canada since 1979 is a result of research concentrated on the taxonomy and faunistics of Canadian species. Most of the research has focused on the most speciose familes (Table 1), the Hemerobiidae (Klimaszewski and Kevan 1985, 1987a, b, 1988, 1989, 1992, Kevan and Klimaszewski 1986, Oswald 1988, 1993, Klimaszewski et al. 2009) and the Chrysopidae (Adams and Garland 1981, Garland 1984, 1985, 2000a, b, Tauber 2003, Penny 2006, Garland and 
Kevan 2007). Other significant works include the review of the Mantispidae of Canada by Cannings and Cannings (2006), the Neuroptera of North America by Penny et al. (1997), and the neuropteroid insects of British Columbia by Scudder and Cannings (2009). As of 2017, more than half of Canadian species have been DNA barcoded and have Barcode Identification Numbers (BINs) (Ratnasingham and Hebert 2013) associated with them (Table 1).

Two of the more notable additions to the Canadian fauna are Nallachius americanus (McLachlan) (Dilaridae) and Ululodes quadripuntatus (Burmeister) (Ascalaphidae) (Garland and Marshall 1980, Prenny and Jones 2017). Each of these species belong to families previously unrecorded in Canada, but were predicted by Kevan (1979) to occur here. The mantidfly, Dicromantispa sayi (Banks) (Mantispidae) is another species that was expected by Kevan (1979) and subsequently recorded in southern Ontario (Cannings and Cannings 2006). The chrysopid, Nineta gravida (Banks) was rediscovered on Canada's Pacific coast after 90 years (Garland 2000b), while the ithonid, Polystoechotes punctatus (Fabricius) appears to be extirpated from the eastern half of North America having not been recorded there since 1952 (Marshall 1996).

Most of the recent increase in species known from Canada has been in the families Coniopterygidae and Hemerobiidae (Table 1). Very little work has been done on the North American Coniopterygidae since Meinander (1974) revised the family (Penny et al. 1997, Meinander et al. 2009). Given their small size and cryptic nature it is likely that research on the Coniopterygidae will yield at least a few new species and distribution records for Canada. BINs for specimens of Coniopterygidae suggest that there may be 20 or more species in this family left to describe. BINs also indicate that there may be several undescribed species of Hemerobiidae, Chrysopidae, and Mymeleontidae.

Hemerobiidae represents a distinctly northern and western group in North America and is the most species-rich family of Neuroptera in Canada with 43 species (70\% of the North American hemerobiid fauna) (Table 1). Kevan and Klimaszewski (1986) characterized the Canadian fauna as "boreo-alpine". Several species are transcontinental in Canada, their ranges extending south into the northernmost parts of the eastern US and along the mountain ranges of the western US. Kevan and Klimaszewski (1986) describe five general distribution patterns for the Hemerobiidae: Holarctic, transcontinental Nearctic, western Nearctic, disjunct Nearctic (western with scattered eastern records) and eastern Nearctic. One species, Wesmaelius longipennis (Banks), was listed by Kevan and Klimaszewski (1986) as endemic to California. However, specimens of W. longipennis in the Canadian National Collection, collected from coastal and interior locations in British Columbia, and one from Quebec, in the 1920s and 1930s, were recently identified (J Klimaszewski pers. comm.). This is a significant extension of the known range and implies that the California records may represent the southern extent of a more widely distributed northern species.

Few Neuroptera in Canada are considered to be exotic species. These introductions include three Coniopterygidae (Conwentzia psociformis (Curtis), Semidalis vicina (Hagen), S. pseudouncinata Meinander), three Hemerobiidae (Psectra diptera (Bur- 


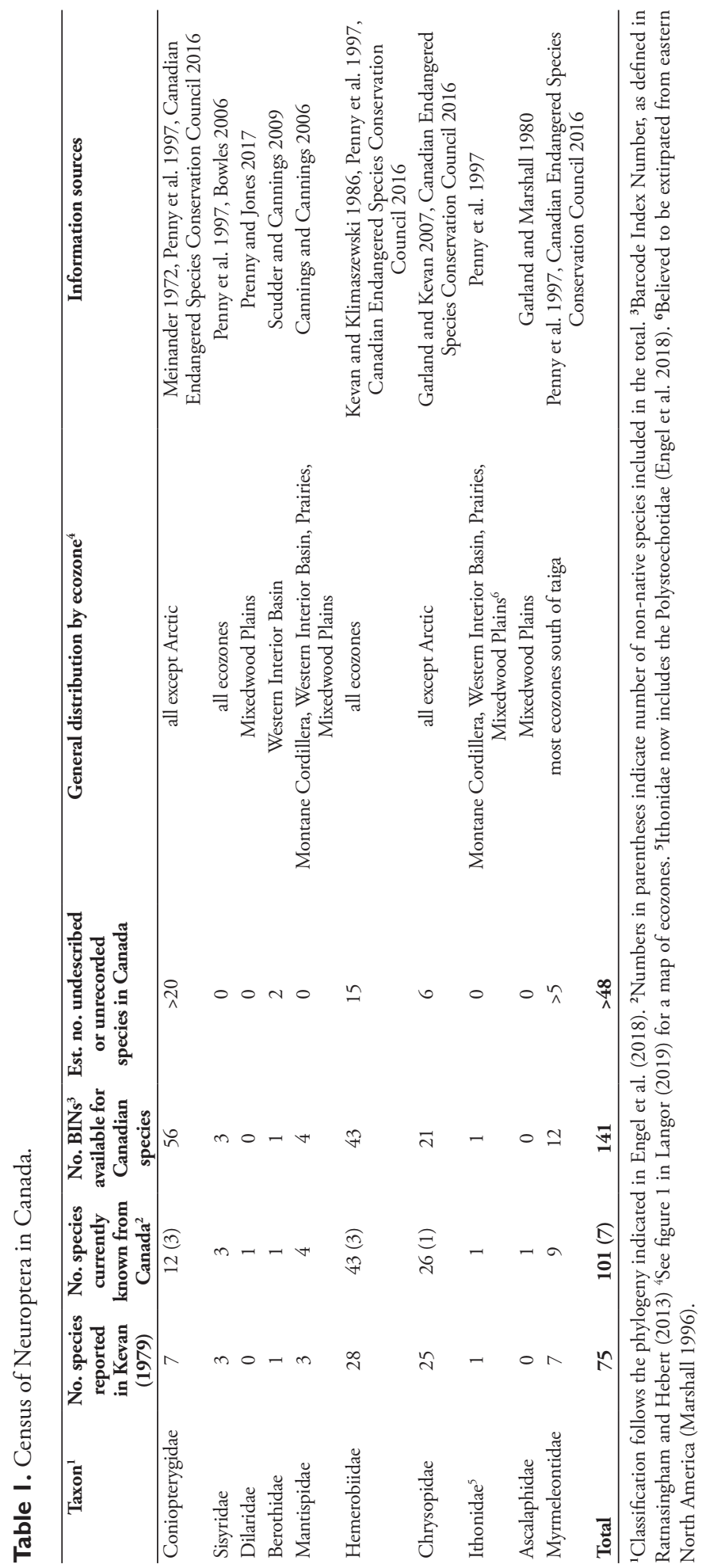


meister), Wesmaelius subnebulosus (Stephens), Micromus variegatus (Fabricius), and the chrysopid, Chrysoperla carnea (Stephens) (Meinander 1972, Kevan and Klimaszewski 1986, Meinander et al. 2009). Chrysoperla carnea, once considered to be of Eurasian origin and introduced to North America (Henry 1983, Brooks 1994) is mass-produced and introduced into agricultural systems as a biocontrol agent (Tauber et al. 2000). Chrysoperla carnea was recently divided into a complex of 15 or more species that are reproductively isolated by their mate-attraction songs (Henry et al. 2011) and analysis of commercially produced specimens labeled as $C$. carnea were in fact dominated by $C$. plorabunda (Fitch) (a North American species) and no C. carnea were present (Henry and Wells 2007).

Future research on Canadian Neuroptera is likely to yield some new species and range extensions in the more diverse families (Table 1). The Paleobiology Database (http://fossilworks.org) indicates that the fossil record has thus far yielded 15 species from three families for Canada, and 68 species in five families for North America, and research on Canadian fossil deposits may reveal additional species. Other interesting avenues of research include the application of native Neuroptera as control agents in agricultural settings, the mating songs of Chrysoperla and the existence of this phenomenon and other mate selection methods in related taxa and systematic revisions of the Myrmeleontidae and Coniopterygidae.

\section{References}

Adams PA, Garland JA (1981) A new species of Chrysopiella Banks from western North America (Neuroptera: Chrysopidae). The Canadian Entomologist 113(1): 1-4. https://doi. org/10.4039/Ent1131-1

Bowles DE (2006) Spongillaflies (Neuroptera: Sisyridae) of North America with a key to the larvae and adults. Zootaxa 1357: 1-19.

Brooks SJ (1994) A taxonomic review of the green lacewing genus Chrysoperla (Neuroptera: Chrysopidae). Bulletin of British Museum of Natural History (Entomology) 63(2): 137-210.

Canadian Endangered Species Conservation Council (2016) Wild Species 2015: The General Status of Species in Canada. National General Status Working Group, 128 pp. http://www. registrelep-sararegistry.gc.ca/virtual_sara/files/reports/Wild\%20Species\%202015.pdf

Cannings RA, Cannings SG (2006) The Mantispidae (Insecta: Neuroptera) of Canada, with notes on morphology, ecology, and distribution. The Canadian Entomologist 138: 531544. https://doi.org/10.4039/n06-806

Garland JA (1984) Catalogue of Chrysopidae of Canada and Alaska (Neuroptera). Neuroptera International 3(2): 93-94.

Garland JA (1985) Identification of Chrysopidae in Canada, with bionomic notes (Neuroptera). The Canadian Entomologist 117: 737-762. https://doi.org/10.4039/Ent117737-6

Garland JA (2000a) The Chrysopidae of Canada (Neuroptera): recent acquisitions chiefly in British Columbia and Yukon. Journal of the Entomological Society of British Columbia 97: 39-40. 
Garland JA (2000b) Rediscovery of Nineta gravida (Banks, 1911) in British Columbia and review of the genus Nineta Navds, 1912 in Canada (Neuroptera: Chrysopidae). Journal of Neuropterology 3: 43-50.

Garland JA, Kevan DK McE (2007) Chrysopidae of Canada and Alaska (Insecta, Neuroptera): revised checklist, new and noteworthy records, and geo-referenced localities. Zootaxa 1486: 1-84.

Garland JA, Marshall BD (1980) Confirmation of Ululodes quadrimaculata in Canada (Neuroptera: Ascalaphidae). The Canadian Entomologist 112: 637-638. https://doi.org/10.4039/ Ent112637-6

Henry CS (1983) Acoustic recognition of sibling species within the holarctic lacewing Chrysoperla carnea (Neuroptera: Chrysopidae). Systematic Entomology (1983) 8: 293-301. https://doi.org/10.1111/j.1365-3113.1983.tb00483.x

Henry CS, Brooks SJ, Johnson JB, Wells MM, Duelli P (2011) Song analysis reveals a permanent population of the Mediterranean Lacewing Chrysoperla agilis (Neuroptera: Chrysopidae) living in central Alaska. Systematics 104(4): 649-657.

Henry CS, Wells MM (2007) Can what we don't know about lacewing systematics hurt us? American Entomologist 53(1): 42-47. https://doi.org/10.1093/ae/53.1.42

Kevan DK McE (1979) Neuroptera. In: Danks HV (Ed.) Canada and its insect fauna. Memoirs of the Entomological Society of Canada No. 108, 354-356.

Kevan DK McE, Klimaszewski J (1986) Notes on the Hemerobiidae or brown lacewing flies (Neuroptera) of Canada and Alaska. Neuroptera International 4(1): 7-22.

Klimaszewski J, Kevan DK McE (1985) The brown lacewing flies of Canada and Alaska (Neuroptera: Hemerobiidae) Part I. The genus Hemerobius Linnaeus: Systematics, bionomics and distribution. Lyman Entomological Museum and Research Laboratory Memoir 15: 1-119.

Klimaszewski J, Kevan DK McE (1987a) The brown lacewing flies of Canada and Alaska (Neuroptera: Hemerobiidae) Part II. The genus Wesmaelius Kruger. Neuroptera International 4(3): 153-204.

Klimaszewski J, Kevan DK McE (1987b) The brown lacewing flies of Canada and Alaska (Neuroptera: Hemerobiidae) Part IIb. The genus Wesmaelius Kruger (continuation). Neuroptera International 4(4): 245-274.

Klimaszewski J, Kevan DK McE (1988) The brown lacewing flies of Canada and Alaska (Neuroptera: Hemerobiidae). Part III. The genus Micromus Rambur. Giomale italiano di Entomologia 4: 31-76.

Klimaszewski J, Kevan DK McE (1989) Distribution data for some Nearctic species of the genus Hemerobius Linnaeus and Wesmaelius Kruger (Neuroptera: Hemerobiidae). Supplement 2. Neuroptera International 5(4): 205-210.

Klimaszewski J, Kevan DK McE (1992) Review of Canadian and Alaskan brown lacewing flies (Neuroptera: Hemerobiidae) with a key to the genera. Part IV: The genera Megalomus Rambur, Boriomyia Banks, Psectra Hagen and Sympherobius Banks. Annals of the Transvaal Museum 35(30): 435-457.

Klimaszewski J, LeSage L, Savard K (2009) First record of adventive species Micromus variegatus (Fabricius) from eastern Canada (Neuroptera, Hemerobiidae). ZooKeys 27: 1-6. https://doi.org/10.3897/zookeys.27.220 
Langor DW (2019) The diversity of terrestrial arthropods in Canada. In: Langor DW, Sheffield CS (Eds) The Biota of Canada - A Biodiversity Assessment. Part 1: The Terrestrial Arthropods. ZooKeys 819: 9-40. https://doi.org/10.3897/zookeys.819.31947

Marshall SA (1996) Polystoechotes punctatus - an extripated giant. Ontario Insects 1: 45.

Meinander M (1972) A revision of the family Coniopterygidae (Planipennia). Acta Zoologica Fennica 136: 1-357.

Meinander M, Klimaszewski J, Scudder GGE (2009) New distributional records for some Canadian Neuropterida (Insecta: Neuroptera, Megaloptera). Journal of the Entomological Society of British Columbia 106: 11-15.

Oswald JD (1988) A revision of the genus Sympherobius Banks (Neuroptera: Hemerobiidae) of America north of Mexico with a synonymical list of the world species. Journal of the New York Entomological Society 96(4): 390-451.

Oswald JD (1993) Revision and cladistic analysis of the world genera of the family Hemerobiidae (Insecta: Neuroptera). Journal of the New York Entomological Society 101(2): 143-299.

Oswald JD, Machado RJP (2018) Biodiversity of the Neuropterida (Insecta: Neuroptera, Megaloptera, and Raphidioptera. In: Foottit RG, Adler PH (Eds) Insect Biodiversity: Science and Society, Volume 1, Second Edition. John Wiley \& Sons Ltd., New Jersey, 627-672. https://doi.org/10.1002/9781118945582.ch21

Penny ND, Adams PA, Stange LA (1997) Species catalog of the Neuroptera, Megaloptera and Raphidioptera of America north of Mexico. Proceedings of the California Academy of Science 50(3): 39-114.

Penny ND (2006) Two new species of Meleoma (Neuroptera: Chrysopidae) from Western North America, with a revised key to species. Annals of the Entomological Society America 99(1): 58-63. https://doi.org/10.1603/0013-8746(2006)099[0058:TNSOMN]2.0.CO;2

Prenny TJ, Jones RJL (2017) A new family to Canada with the discovery of Pleasing Lacewing (Nallachius americanus; Neuroptera, Dilaridae) at the Ojibway Prairie Complex in Windsor, Ontario. Journal of the Entomological Society of Ontario 148: 39-41.

Scudder GGE, Cannings RA (2009) A checklist of the neuropteroid insects of British Columbia (Insecta: Megaloptera, Neuroptera and Raphidioptera) with a summary of their geographic distribution. Journal of the Entomological Society of British Columbia 106: 17-23.

Tauber CA (2003) Generic characteristics of Chysopodes (Neuroptera: Chrysopidae), with new larval descriptions and a review of species from the United States and Canada. Annals of the Entomological Society America 96(4): 472-490. https://doi.org/10.1603/00138746(2003)096[0472:GCOCNC]2.0.CO;2

Tauber MJ, Tauber CA, Daane KM, Hagen KS (2000) Commercialization of predators: recent lessons from green lacewings (Neuroptera: Chrysopidae: Chrysoperla). American Entomologist 46(1): 26-38. https://doi.org/10.1093/ae/46.1.26 